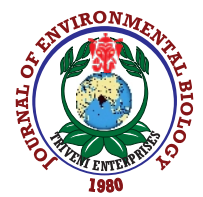

\title{
Studies on the distribution and diversity of helminth infection in Xenentodon cancila (Hamilton, 1822) in Mizoram, Northeast India
}

\author{
C. Malsawmtluangi and Lalramliana* \\ Department of Zoology, Pachhunga University College, Aizawl-796 001, India \\ *Corresponding Author Email : Irl_zoo@yahoo.co.in
}

\begin{abstract}
Aim: The aim of the present study was to document the diversity of endoparasitic helminth in fresh water garfish, Xenentodon cancila and to assess, their zoonotic potential if any.

Methodology: The collections of fishes were conducted in rivers of Mizoram and parasites were retrieved. Morphological identification was done by following various taxonomic keys.

Results : A total of 40 specimens of garfish were collected from six different locations. Only two taxonomic groups of helminth parasites were recorded; Trematoda (Platyhelminthes)-including three species- one each representing the genera Prosorhynchoides, Phyllodistomum and Plagioporus; and Acanthocephala- represented by Neoechinorhynchus. No cestode or nematodes were recorded from this piscine host.

Interpretation: The results revealed that prevalence, mean intensity and abundance were found to be highest in fishes collected from river Tuikum followed by Tuirial. No helminth infection was found in the fishes collected from Chhimtuipui and Tlawng Rivers. Further, no potential zoonotic helminths were recorded in the present studies. All the parasites reported in the present study constitute the first report from the state of Mizoram.
\end{abstract}

Keywords: Acanthocephala, Helminth parasites, Trematoda, Xenentodon cancila

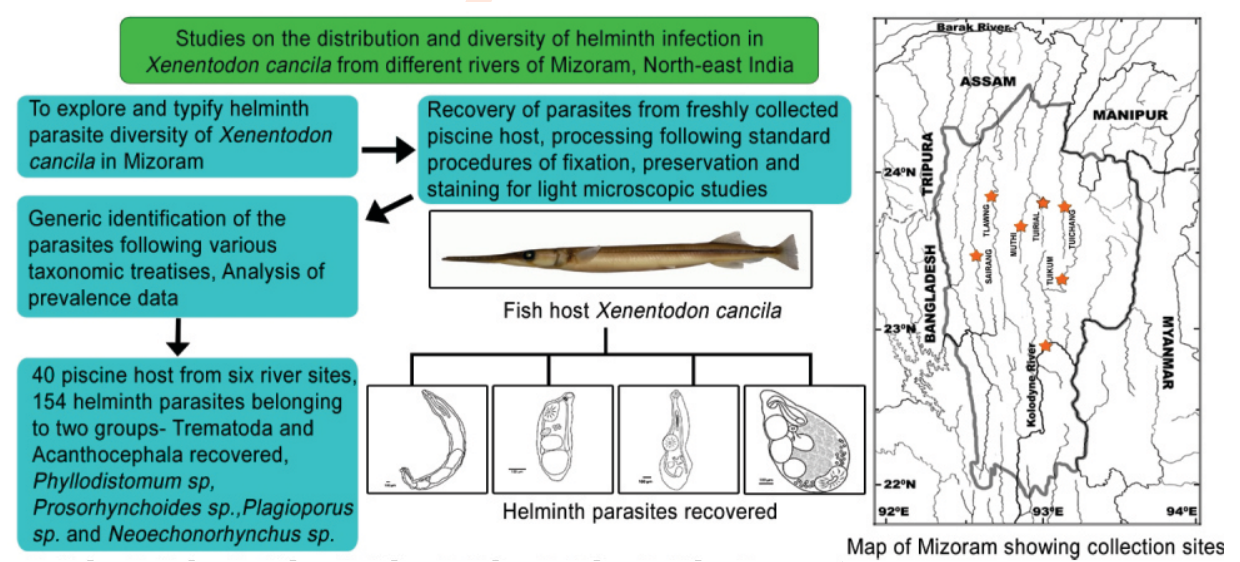

How to cite : Malsawmtluangi, C. and Lalramliana: Studies on the distribution and diversity of helminth infection in Xenentodon cancila (Hamilton, 1822) in Mizoram, Northeast India. J. Environ. Biol., 41, 832-839 (2020). 


\section{Introduction}

Fishes constitute an important part of the local delicacies and have been extensively used as a source of protein, especially for the rural area, in Mizoram, Northeast India. However, fishes serve as hosts to number of helminth parasites, some of which can even turn out to be potential zoonotic parasites. Helminths cause both infection and diseases in freshwater and marine fishes, their importance being related directly to the fish that may affect the general public health (Hoffman, 1967). Certain helminth parasites are a matter of major public health concern (Yooyen et al., 2006). In addition, they may also cause economic loss to farmers, as parasites also compete for food with the fish host, thus, depriving fish of essential nutrients and inhibiting growth leading to morbidity and mortality (Khalil and Polling, 1997).

Consumption of raw or under cooked or processed fish can be the main source of infection for humans, with number of cases being reported from different geographical regions (Park et al., 2009). The worldwide number of people infected with small liver flukes only exceeds 45 million and many more are at risk (Keiser and Utzinger, 2009). More than 30,000 helminth parasites have been reported to infect fishes and many of them are harmful to their hosts. Dependency of the parasite on its host and exploitation of the fishes by the helminth parasites provide a useful research model in the field of ecology and evolutionary biology. Studies on the helminth parasitic spectrum in freshwater fishes have been carried out in different parts of the world. In India, many researchers have worked on the helminth parasites of both freshwater and marine fishes, describing new species and have made further advancements in this field using various molecular biological tools,(Dayal, 1949; Srivastava, 1982; Dhole et al., 2010). However,in the context of North-east India, reports on this field are meager, and very limited reports are available. Most of the reports are from Manipur, Meghalaya and Assam, where, Shomorendra et al. (2005) reported five helminth parasites of fishes from Loktak lake Manipur; Tandon et al. (2005), Thapa et al. (2008) and Jyrwa et al. (2014) reported and made a checklist on the helminth parasite of fishes from Meghalaya; Binky et al. (2011) reported three species of Nematode in Anabas testudineus in Assam; Singha et al. (2015) reported Nematode, Cestode, Trematode and Acanthocephala from three different species of fish from Dolu lake, Silchar, Assam and Koiri and Roy (2016) reported nine different species of helminth parasites in Clarias batrachus from Tripura.

In Mizoram, no work has been done to explore the diversity of helminths infecting freshwater fishes. Among many freshwater fishes, predatory fish species harbor a greater diversity and abundance of helminths, compared to herbivorous and planktivorous species (Luque and Poulin, 2004). The present study was undertaken to find out the helminth parasitic spectrum of the predatory fish, Xenentodon cancila, from Mizoram Northeast India.

\section{Materials and Methods}

Study area: The state of Mizoram covering an area of 21,081 km with geographical isolates of $23.1645^{\circ} \mathrm{N}, 92.9376^{\circ} \mathrm{E}$ is situated in the southern part of North-eastern India, bordering Bangladesh in the south-west and Myanmar in the east. The major rivers of Mizoram are Tuirial, Tlawng, Tuirini, Tuivai, Mat, Kolodyne, Tuichawng, Karnafuli and Serlui, which can be categorized under three major drainage systems, Barak-Meghna drainage system, Indo-Bangladesh; Kolodyne (Kaladan) drainage system, IndoMyanmar and Tuichawng-Karnafuli drainage system, IndoBangladesh.

Sample collection and morphological analysis: Fishes collected from different rivers were brought to the laboratory. Their external body surface was examined for the presence of ecto-parasites. Fishes were dissected and their internal organs such as heart, lungs, liver, spleen, stomach, intestine, swim bladder, gonads and mesenteries etc., were examined thoroughly for the presence of helminth parasites under dissecting microscope. The helminth parasites recovered were counted, stretched and they were gently flattened between a glass slide and a cover slip, tied with thread and fixed overnight in $70 \%$ ethyl alcohol inside a coplin jar. Whole mount preparations were made by staining with Borax carmine, and dehydrated through ascending grades of alcohol, cleared in methyl benzoate and finally mounted using Canada balsam. The permanent slides were observed and studied under stereo microscope. A highresolution image of the parasites was obtained using stereo microscope in a series of adjacent focal planes. Measurements of the specimens were taken using stage and ocular micrometers. All measurements are expressed in $\mathrm{mm}$ unless otherwise stated.

For taxonomic identification of parasites, standard reference works of Yamaguti $(1971,1963 b, 1958)$. Keys to the Trematoda Vols. 1-3 (Gibson et al., 2002, Jones et al., 2005, Bray et al., 2008) were referred.

Analysis of prevalence data: Data were recorded on the prevalence and intensity of helminth infection in piscine hosts and the data were analyzed following Bush et al. (1997):

Prevalence $(P)=$ the number of infected host with one or more individuals of a particular parasites species (or taxonomic group) divided by the number of hosts examined.

Mean intensity $(\mathrm{MI})=$ the average intensity, i.e., the total number of parasites of a particular species found in a sample divided by the number of hosts infected.

Abundance $(A)=$ the total number of individuals of a particular parasite species in a sample of a particular host species divided by the total number of hosts (including both infected and uninfected) of that species examined. 
Statistical Analysis: One-way analysis of variance (ANOVA) was performed using SPSS 20.0 to ascertained and analyse the significant of variation (at $p \leq 0.05$ ) at different sites.

\section{Results and Discussion}

The present study gives the first report on the presence of helminth parasites in the fish host, Xenentodon cancila from Mizoram, North-east India. During the study period, a total of 40 fishes were examined from 6 different locations, where 154 helminth parasites were recorded belonging to two different groups, Trematoda and Acanthocephala. Prevalence, Abundance and Mean Intensity was found to be highest in the fishes collected from Tuikum followed by Tuirial, Tuichang and Muthi Rivers, but no parasites were retrieved from the fishes collected from Chhimtuipui and Tlawng Rivers (Table 1). Statistical analysis confirmed significant variations on the prevalence of parasites within the six collection sites $(F=8.160$, df $=5,34$; and $p<0.05$ ). Furthermore, the occurrence of the four species of parasites in the host $X$. cancila showed significant variations $(F=15.854, \mathrm{df}=3,156 ; \mathrm{p}<0.05)$. The trematode parasites collected belonged to the genus Prosorhynchoides sp., Plagioporus sp., Phyllodistomum sp. while Neoechinorhynchus sp. belonged to Acanthocephala. The genus Prosorhynchoides sp. was found to be the most prevalent group of parasites $(50 \%)$ followed by Plagioporus sp. (17.5\%), Phyllodistomum sp. (7.5\%) while Neoechinorhynchus sp. (5\%) was the least prevalent among the helminth parasites collected. Mean intensity was also found to be highest in Prosorhynchoides sp. (6.3) followed by Neoechinorhynchus sp. (2.5), Plagioporus sp. (2.43) and Phyllodistomum sp. (2). The abundance of Prosorhynchoides sp.

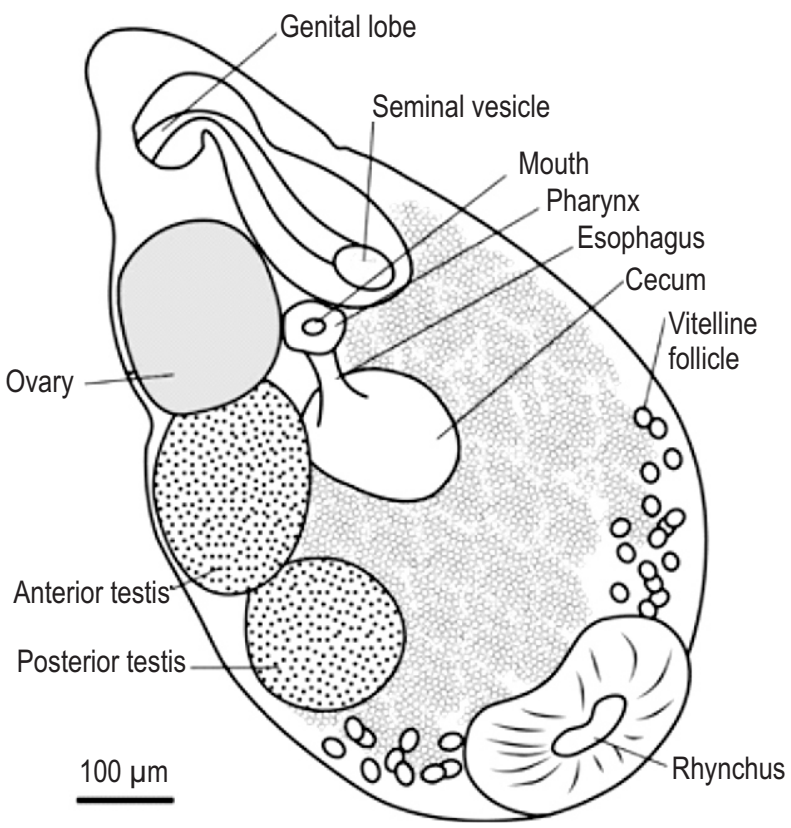

Fig. 1 : Ventral view of Prosorhynchoides sp.
(3.15) was highest, followed by Plagioporus sp. (0.45), Phyllodistomum sp. (0.15) and Neoechinorhynchus sp. (0.12) (Table 2). The overall prevalence, mean intensity and abundance was highest in the fishes collected from the river Tuikum, located in Serchhip district of Mizoram followed by the fishes collected from river Tuirial. No cestode or nematode parasites were collected during the study period.

\section{Parasitic spectrum: Trematoda}

Family: Bucephalidae Poche, 1907; Genus: Prosorhynchoides Dollfus, 1929; Host: Xenentodon cancila; Locality: Tuikum; Site of infection: Intestine

Description: Body small, inversely pear-shaped, broader at the anterior region than posterior. Body measured $0.168-1.10 \mathrm{~mm}$ in length and maximum width was $0.441-0.576 \mathrm{~mm}$ at post oral region. Rhynchus (anterior sucker) was large. Digestive cecum globular sac like, usually lies at level of anterior testis. Ovary pretesticular, testes somewhat oval, cirrus sac cylindrical, extended from level of anterior or posterior testis to slightly posterior end of the body. Genital pore terminal at posterior extremity. Vitellaria compact, in 2 groups each with 14-15 rounded follicles arranged in lateral body spaces, anterior extent of vitellaria upto rhynchus.

Remarks: The genus Prosorhynchoides was established by Dollfus (1929), with the type species being Prosorhynchoides ovatus Linton 1900, having a simple sucker for a rhynchus. Based

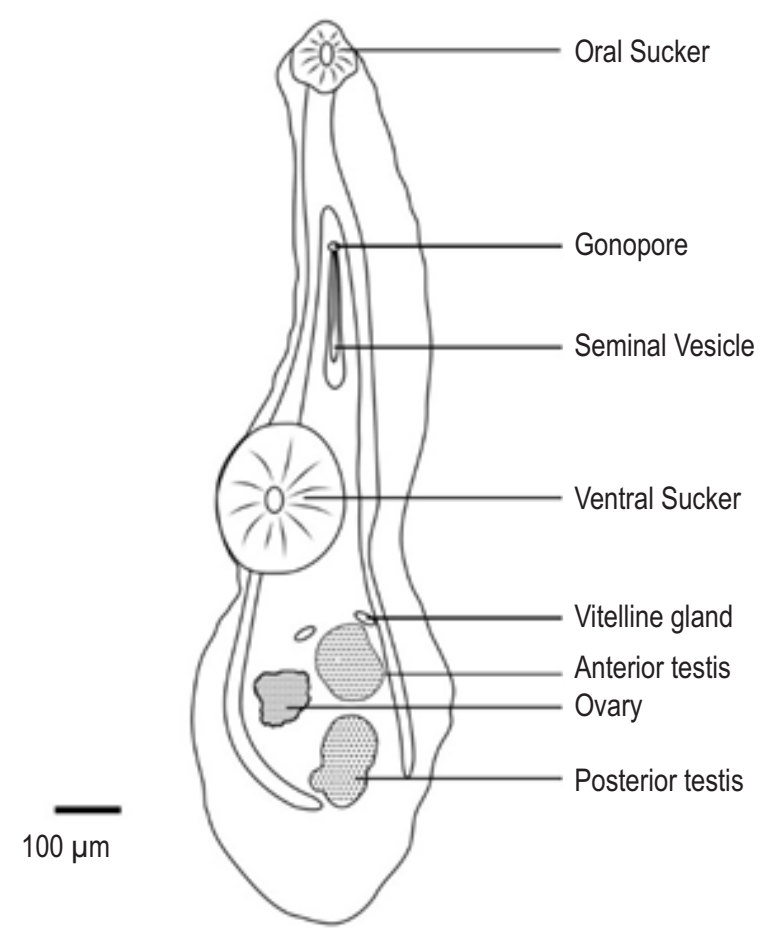

Fig. 2 : Ventral view of Phyllodistomum sp. 
Table 1 : Diversity of helminth parasites in different collection sites

\begin{tabular}{lllllll}
\hline Locality (Rivers) & $\begin{array}{l}\text { No of host } \\
\text { examined }\end{array}$ & $\begin{array}{l}\text { No of host } \\
\text { infected }\end{array}$ & $\begin{array}{l}\text { Total No of } \\
\text { parasites }\end{array}$ & Prevalence (\%) & Mean intensity & Abundance \\
\hline Tuirial & 15 & 11 & 58 & 73.34 & 5.28 & 3.86 \\
Tuichang & 9 & 6 & 17 & 66.67 & 2.84 & 1.89 \\
Tuikum & 5 & 4 & 73 & 80 & 18.25 & - \\
Chhimtuipui & 2 & - & - & - & - & - \\
Tlawng & 5 & - & - & 50 & 3 & 1.6 \\
Muthi & 4 & 2 & 6 & & & - \\
\hline
\end{tabular}

Table 2 : Prevalence of helminth parasites in Xenentodon cancila

\begin{tabular}{lllllll}
\hline Helminth parasites & $\begin{array}{l}\text { No of host } \\
\text { examined }\end{array}$ & $\begin{array}{l}\text { No of host } \\
\text { infected }\end{array}$ & $\begin{array}{l}\text { Total No of } \\
\text { parasites }\end{array}$ & $\begin{array}{l}\text { Prevalence } \\
\text { (\%) }\end{array}$ & Mean Intensity & Abundance \\
\hline Phyllodistomumsp. & 40 & 3 & 6 & 7.5 & 2 & 0.15 \\
Prosorhynchoidessp. & 40 & 20 & 126 & 50 & 6.3 & 3.15 \\
Plagioporus sp. & 40 & 7 & 17 & 17.5 & 2.43 & 0.42 \\
Neoechinorhynchus sp. & 40 & 2 & 5 & 5 & 2.5 & 0.12 \\
\hline
\end{tabular}

on the presence of a simple sucker-like rhynchus, ovary anterior to the testes, and a ventrally located mouth. The present specimen belonged to the genus Prosorhynchoides.

Several species of the genus Prosorhynchoides have been described from the freshwater fishes in India including the checklist, redescription and reviewing of the genus (Chauhan, 1954; Srivastava and Chauhan, 1973; Pandey and Tiwari, 1984; Sen, 2014; Maurya et al., 2018). Our specimen was found close to $P$. karvei retrieved from $X$. cancila collected from Gomti river, Lucknow. Comparing their similarities both were more or less similar in size, having a small oval pear shaped body and ovary pre-testicular, the mouth opened at the mid level of the posterior testis and both had globular saclike cecum, and the uterus extended upto the rhynchus (filling most of the anterior body), and possessed ovary well above the level of pharynx, but differed in the extent of the cirrus sac as in our specimen the tubular cirrus sac extended up to the level of anterior testis and differed in the no of their vitelline follicles and by not having any spines on its teguments. This is the first report on the occurrence of the genus Prosorhynchoides from Mizoram.

Family: Gorgoderidae Looss, 1899; Genus: Phyllodistomum Braun, 1899; Host: Xenentodon cancila; Locality: Tuirial; Site of infection: Intestine

Description: Body dorsoventrally flattened, slightly spatulate, divided into a narrow tubular, curved fore body and posterior part of the body extended into bolbous shape. Measuring1.48mm in length and $0.45 \mathrm{~mm}$ in width across the widest portion. Oral sucker, terminal, slightly oval measuring $0.18 \times 0.15 \mathrm{~mm}$, mouth opening ventrally, no noticeable papillae on oral sucker. Ventral sucker measuring $0.27 \times 0.23 \mathrm{~mm}$ was larger than oral sucker.
Muscular pharynx present. Ovary oval parallel to anterior testis, post-equatorial, testes two in number located in the broadest part of hind body, post-equatorial, tandem, inter-caecal and lobed.

Remarks: The genus Phyllodistomum was erected by Braun (1899) for Distomum folium Olfers, 1816 as its type species. Based on the narrow and tubular anterior region and spatulated hind body our specimen belonged to the genus Phyllodistomum. Phyllodistomum Braun, 1899 (Trematoda: Gorgoderidae) comprising more than 110 species, and is one of the two largest genera of trematodes (Kudinova 1994; Cribb et al., 2002). Different species of the genus Phyllodistomum have been described by several workers in India; these are $P$. spatulaeforme Odhner, 1902; P. lewisi Srivastava, 1938; P. macronium (Dayal, 1938) Yamaguti, 1958; P. callichrius Dayal, 1942; $P$. vachius Dayal, 1949; P. loossi Kaw,1950; P. singhiai Gupta, 1951; P. vittatusi Gupta, 1955; P. parorchium Jaiswal, 1957; P. indianum Jaiswal, 1957; $P$. chauhani Motwani and Srivastava, 1961; $P$. tripathi Motwani and Srivastava, 1961; P. srivastavi Rai, 1964; $P$. cameroni Agarwal, 1966. Recently P. triangulata Sarwat, 2011; $P$. laximibai Sen and Siddiqui,2013; $P$. betwaensis Sen, 2014; $P$. batrachii Vankara et al., 2016 and $P$. punctati Jithila and Prasadan, 2018). Our specimen differs in the shape and size of the oral sucker and the vitelline gland when compared with $P$. laxmibai described from the same fish host $X$. cancila. $P$. batrachii resemble our specimen with regards to the size and overall morphology, however, the size of the acetabulum and the anterior part is markedly different from our specimen. $P$. punctati from $C$. punctata in the Western Ghat, is much broader and bigger in size and the oral sucker is larger than the ventral sucker (vs. the ventral sucker is larger than oral sucker in our specimen). Nevertheless, the present study is the first report on the occurrence of the genus Phyllodistomum from the state of Mizoram. 
Family: Opecoelidae Ozaki, 1925; Genus: Plagioporus Stafford,1904; Host: Xenentodon cancila; Locality: Tuikum; Site of infection: Intestine

Description: Body elongate measuring 0.8-0.97x0.24-0.25 mm, a spinose, forebody distinctly tapered, oral sucker terminal, oral sucker visibly smaller than acetabulum $0.15 \times 0.14 \mathrm{~mm}$ which is located in anterior of the body, testes tandem in posterior third of the body anterior testis $0.11 \times 0.13 \mathrm{~mm}$, posterior testis $0.14 \times 0.15 \mathrm{~mm}$ eggs large measuring $0.06 \times 0.02 \mathrm{~mm}$ and elliptical in shape, Ovary ovoid just anterior to anterior testis, pharynx located behind the anterior sucker, Vitellaria extending to the anterior region near the acetabulum.

Remarks: In India, the genus Plagioporus Stafford, 1904 is represented by only one species, Plagioporus panchax found in freshwater fishes. Our specimen was much smaller in size as compared to $P$. panchax and $P$. (Caudotestis) mujibi described by Bilquees (1972) from Pakistan. Mukesh and Gambhir (2016) have reported a new species $P$. (Caudotesti) minutus in loach, Schistura manipurensis from Manipur which was smaller in size as compared to our specimen. The present study gives the first report on the occurrence of Plagioporus sp. from the state of Mizoram.

Acanthocephala; Family: Neoechinorhynchidae Van Cleave, 1919; Genus : Neoechinorhynchus Hamann, 1892; Host: Xenentodon cancila; Locality: Tuichang; Site of infection: Intestine

Description: Acanthocephala was found in the fishes collected from Tuichang river only. Male body was $5.6 \mathrm{~mm}$ long and the

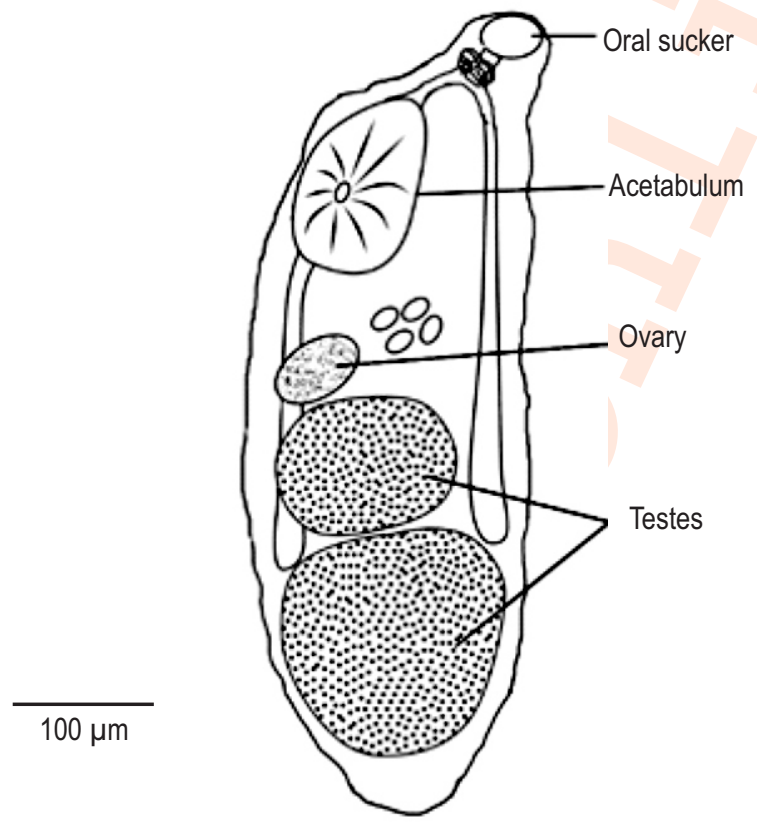

Fig. 3 : Ventral view of Plagioporus sp. broadest region measured $0.5 \mathrm{~mm}$. Trunk aspinose, small, cylindrical bowed or straight, proboscis short somewhat globular, proboscis receptacle subcylindrical somewhat short, lemnisci digitiform to filiform, lemnisci twice as long as proboscis sheath, testis in posterior half of the trunk, testis oval, cement gland syncytial and cement reservoir rounded, everted bursa, proboscis receptacle short, simple, single-walled sac. Lemnisci slender, elongate, unequal.

Remarks: Hamann (1892) described the genus Neoechinorhynchus with type species $N$. ruttili. Neoechinorhynchus are parasites of freshwater, brackish water and marine fishes, also of amphibians and chelonian. Even though in our specimen the proboscis was not everted but considering the body shape and size, arrangement and shape of the testis, unequal lemnisci, shape of cement gland and cement reservoir confirmed genus Neoechinorhynchus. Bhatacharya (1998) reported 140 species of Acanthocephala from fishes in India, indicating high degree of regional endemism. A total of 18 species of Neoechinorhynchus sp. were reported from fishes in India (Tripathi, 1959; Chandra et al., 1985). Since the proboscis is not fully everted in our specimen, the number of spines cannot be ascertained, and, the absence of female specimen makes it difficult to identify upto the species level. This is the first report on the occurrence of Neoechinorhynchus sp. from the state of Mizoram. The high prevalence, mean intensity and abundance of parasites of fishes collected from Tuikum and Tuirial Rivers may be attributed to the fact that both these rivers flow near human settlement, especially river Tuirial which is located near the city dumping ground. This is in agreement with the reports of Moller

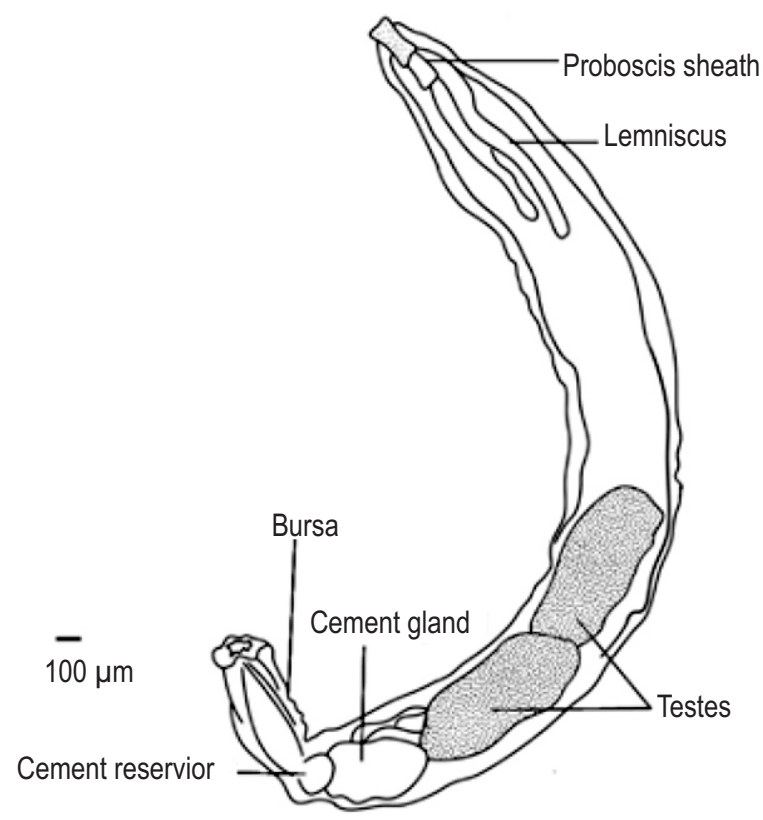

Fig. 4 : Ventral view of Neoechinorhynchus sp. male. 
and Anders (1986) who concluded that fish from more polluted water tend to harbor more helminth parasites than those from less polluted waters. Subsequently, People living near fresh water bodies were found to have a 2.15 -fold higher risk of parasitic infections than those living farther from the water (Keiser and Utzinger, 2005). However, no parasites were recovered from the fishes collected from Tlawng and Chhimtuipui Rivers which may be attributed to the availability of fewer fish host.

Of all the specimen collected in this study, the genus Prosorhynchoides sp. was the most prevalent and abundant group whereas Acanthocephala showed minimum prevalence. Similar to our findings, Kundu et al. (2015) reported that among the helminth parasites collected from C. punctata in West Bengal, an Acanthocephalan group showed minimum prevalence. Contrastingly, Ningthoukhongjam et al. (2015), from Manipur, reported that the Acanthocephalan infection in C. striata was as high as 100\%. Gautam et al. (2018) reported that an Acanthocephalan, Pallisentis sp., was the most prevalent and abundant group in Channa sp. (46.5\% in C. punctata and $59.11 \%$ in C. striata). The differences in prevalence, mean intensity and abundance of the parasites may be attributed to various environmental factors such as physico-chemical factors of the water, geographical location of the collection sites and fauna present in and around the habitat etc., which can affect the hostparasite relationship. Many studies were performed on the helminth parasitic fauna of freshwater fishes, its frequency and distribution in many parts of the world.

Fish borne helminth zoonoses is an important part of food borne helminth zoonoses (Eiras et al., 2018). At least 13 species of Diphyllobothrium have been reported from humans, with infections by $D$. latum and $D$. dentriticum being the most prevalent, (Adam et al., 1997). With approximately 20,000 reported worldwide Anisakidosis is the most representative fishborne nematodiasis. Most cases of human infections are caused by Anisakis simplex, A. physeteris and Pseudoterranova decipiens (Hochberg et al., 2010). Capillaria phillipinensis which cause intestinal capillariasis had been considered to be one of the important zoonoses. It was first found in northern Luzon, Phillipines (Cross et al., 2007) and further reported from Northeast Thailand (Saichua et al., 2008). Another important fish borne parasite, Clonorchis sinensis, is prevalent in Asian countries including South Korea, China, northern Vietnam and far-eastern Russia (Rim, 2005; Qian et al., 2016). Currently, over 15 million people are infected with $C$. sinensis worldwide, and 1.5-2 million people show symptoms or complications (Hong and Fang, 2012). Most cases of clonorchiasis occur in low- or middle-income countries of Asia and almost 5591 people died from the infection each year (Furst et al., 2012). Considering their zoonotic importance and their effect on humans it would be interesting to find out their occurrence in our study. However, we did not come across any of these important zoonotic helminths and no records were available within our study areas.
Helminth parasites are important as they not only cause diseases in fishes but also, form an essential component of global biodiversity (Poulin and Morand, 2004). In India, studies on the diversity of helminth parasites of different freshwater fishes has been carried out by several researchers, however, reports on the parasites of this particular fish $X$. cancila is meagre. Sharmin et al. (2003) had reported the endoparasitic helminth of $X$. cancila in Bangladesh, in which they showed the presence of trematode, Acanthocephala and a Nematode, but, all the species that they reported were different from this study. In Bangladesh, Hoque et al. (2006) reported two monogenean and one cestode from Mystus aor where they reported Bucephalopsis karvei (a synonym of Prosorhynchoides karvei) from X. cancila, similar to our present report. Beevi and Radhakrishnan (2012) reported the metazoan parasites of freshwater fishes from Kerala and found that the family Belonidae (to which $X$. cancila belong) showed the lowest parasitic fauna. The present studies contribute in enriching the data on helminth parasitic diversity of $X$. cancila from Mizoram, North-east India. Kennedy et al. (1986) demonstrated that the parasite fauna of freshwater birds and mammals are richer and more diverse as compared to fresh water fishes, and that, species richness and mean intensity of parasites of freshwater fishes is less than that of marine fishes. This conforms our findings in which only three Digenea and one Acanthocephala species have been reported and no cestode or nematode are retrieved.

In conclusion, the helminth communities of the freshwater fish, $X$. cancila, in Mizoram are species-poor, and that, considerable proportion of fish from the region is uninfected or lightly infected. A detailed account on the helminth parasitic infection of fishes in the region covering larger areas and wider species of fish hosts need to be investigated. Further work is required to supplement the morphological study with molecular data in order to accurately identify the helminth parasites.

\section{Acknowledgments}

The research work is funded by National Mission on Himalayan Studies (NMHS), GBPNIHESD under Himalayan Fellowship (U/I ID: HSF2018-19//-25/03) (Sanction No. GBPNI/NMHS-2018-19/HSF25-03/154; Dt 17.12.2018). The authors are thankful to the Principal, PUC; Head, Department of Zoology, PUC; and Institutional Biotech-Hub (Advance Level), PUC for providing infrastructural support.

\section{References}

Adams, A.M. and R.L. Rausch: Diphyllobothriasis. In: Pathology of Infectious Diseases (Eds.: D.H. Connor, F.W. Chandler, D.A. Schwartz, H.J. Manz and E.E. Lack). Appleton Lange, Stamford, 2, 1377-1389 (1997).

Agarwal, V.: Studies on some trematode parasites of freshwater fishes from Lucknow. Ann. Parasitol., 24, 217-231 (1966).

Beevi, M.R. and S. Radhakrishnan: Community ecology of the metazoan 
parasites of freshwater fishes of Kerala. J. Parasit. Dis., 36, 184-96 (2012).

Bilqees, F.M.: Marine fish trematodes of West Pakistan IX. Two new species Plagioporus (Caudotestis) mujibi and Notoporus hystrix (Digenea: Allocreadiidae). In: Helminth parasites of some vertebrates chiefly from fishes of West Pakistan Karachi. (Eds.: F.M. Bilqees, R. Saaed, R. Rehana, A. Khatoon and S.H Kaikabad). Agric. Res. Counc., pp. 105-110 (1972).

Bhattacharya, S.B.: "Acanthocephala." Faunal Diversity in India. Zoological Survey of India, Kolkata, India, pp. 93-98 (1998).

Binky, K., T. Ranibala, M. Shomorendra and D. Kar: Diversity of helminth parasites in fishes of Karbhala Wetland in Cachar district of Assam. Enviro. Ecol., 29, 20-21 (2011).

Braun, M.: Ein neues Distomumaus Porphyrio. Zool. Anz., 22, 1-4 (1899).

Bray, R.A., D.I. Gibson and A. Jones: Keys to the Trematoda, Vol 3. CAB International, Wallingford, p. 824 (2008).

Bush, O., A.D. Lafferty, J.M. Lotz and A.W. Shostak: Parasitology meets ecology on its own terms: Margolis et al. revisited. J. Parasitol., 83, 575-583 (1997).

Chandra, K.J.K., H. Rao and K. Shyamasundari: On Neoechino rhynchus argentanus $\mathrm{n}$. $\mathrm{sp}$., an acanthocephalan parasite from a marine fish of Waltair. Riv. Parasitol., 45, 49-52(1985).

Chauhan, B.S.: Studies on trematode fauna of India. Part III. Subclass Digenea (Gasterostomata). Records Indian Museum, 51, 231-287 (1954).

Cribb, T.H., R.A. Bray, T. Wright and S. Pichelin: The trematodes of groupers (Serranidae: Epinephelinae): Knowledge, nature and evolution. Parasitology, 124, 23-42 (2002).

Cross, J.H. and V. Belizario: Capillariasis. In: Food Borne Parasitic Zoonoses (Eds.: K.D. Murrell and B. Fried) New York, USA. Sprin. Sci. Busin. Med., pp. 209-234 (2007).

Dayal, J.: A new trematode, Phyllochorus macronium n.g., n.sp., belonging to the family Gorgoderidae Looss, 1901, from the body cavity of a freshwater fish Macrones tengara. Proc. Ind. Acad. Sci., 7,138-142 (1938).

Dayal, J.: On a new trematode Plesiodistomum callichrius n.g., n.sp., from the urinary bladder of a freshwater fish Callichrous pabda. In: Proc. Ind. Sci. Cong., Part III, p. 171 (1942).

Dayal, J.: Trematode parasite of Indian fishes part II. Indian. J. Helminthol., 1, 93-116 (1949).

Dollfus, R.P.: Helminths I. Trematoda and Acanthocephala. Faune des Colonies Françaises, 3, 73-114 (1929).

Dhole, J., S. Jawale, S. Waghmare and R. Chavan: Survey of helminth parasites in freshwater fishes from Marathwada region, MS, India. J. FishAquacul., 1, 1-7 (2010).

Eiras, J.C., G.C. Pavanelli, R.M. Takemoto and Y. Nawa: An overview of fish-borne Nematodiases among returned travelers for recent 25 years- Unexpected diseases sometimes far away from the origin. Korean J. Parasitol., 56, 215-227 (2018).

Fürst, T., J. Keiser and J. Utzinger: Global burden of human food-borne trematodiasis: A systematic review and meta-analysis. Lancet. Infect. Dis., 12, 210-21 (2012).

Gautam, N.K., P.K. Misra and A.M. Saxena: Seasonal variation in helminth parasites of snakeheads Channa Punctatus and Channa striatus (Perciformes: Channidae) in Uttar Pradesh, India. Helminthologia, 55, 230-239 (2018).

Gibson, D.I., A. Jones and R.A. Bray: Keys to the Trematoda. Vol 1.CAB International, Wallingford, p.509(2002).
Gupta, S.P.: On a new trematode, Phyllodistomum singhiai $n$. sp. of the family Gorgoderidae Looss, 1899 from the intestine of freshwater fish, Mastacembelus armatus (Lacep.). Indian J. Helminthol., 3, 21-28 (1951).

Gupta, S.P.: Trematode parasites of freshwater fishes. Indian J. Helminthol., 5, 1-80 (1955).

Hamann, O.: Das system der Acanthocephalen. Zool. Anz., 15, 195-197 (1892).

Hochberg, N.S., D.H. Hamer, J.M. Hughes and M.E. Wilson: Anisakidosis: Perils of the deep. Clin. Infect. Dis., 51, 806-812 (2010).

Hoffman, G.L.: Parasites of North American Freshwater Fishes. University of California Press, Berkeley, p. 486 (1967).

Hong, S.T. and Y.Y. Fang: Clonorchis sinensis and clonorchiasis, an update. Parasitol. Int., 61, 17-24 (2012).

Hoque, N., K.J. Chandra and A.K. Bakshi: Abundance of some helminth parasites in indigenous freshwater fishes of Bangladesh. $J$. Bangladesh Agril. Univ., 4, 357-364 (2006).

Jaiswal, G.P.: Studies on the trematode parasites of fishes and bird found in Hyderabad State. Part IV. Zool. Anz., 85, 62-64 (1957).

Jithila, P.J. and P.K. Prasadan: Prevalence, intensity, mean abundance and description of Phyllodistomum punctati n. sp. (Digenea: Gorgoderidae) from the urinary bladder of Channapunctata (Bloch) from the Western Ghats, India. Int. J. Fish Aquat. Stud., 6, 01-05 (2018).

Jones, A., R.A. Bray and D.I. Gibson: Keys to the Trematoda, Vol 2. CAB International, U.K. p. 733 (2005).

Jyrwa, D.B., S. Thapa and V. Tandon: Helminth parasite spectrum of fishes in Meghalaya, Northeast India: A checklist. J. Parasit. Dis., 40, 312-329 (2014).

Keiser, J. and J. Utzinger: Emerging foodborne trematodiasis. Emerg. Infect. Dis., 11, 1507-1514 (2005).

Keiser, J. and J. Utzinger: Food-borne trematodiases. Clin. Microbiol. Rev., 22, 466-83 (2009).

Kaw, B.L.: Studies in helminthology: Helminth parasites of Kashmir. Part I.Trematoda. Indian J.Helminthol., 2, 67-69 (1950).

Kennedy, C.R., A.O. Bush and J.M. Aho: Patterns in helminth community. Why are birds and fishes different? Parasitology, 93, 205-215 (1986).

Khalil, L.F. and L. Polling: Checklist of the helminth parasite of African freshwater fishes. University of North. Republic of South Africa, p. 161 (1997)

Koiri, R. and B. Roy: The seasonal incidence of parasitic helminth infection among the walking catfish, Clarias batrachus of Tripura, India. Ann. Parasitol., 62, 307-314 (2016).

Kudinova, M.A.: On the revision of system of the trematode genus Phyllodistomum Braun, 1899 (Gorgoderidae). Ecol. Parasitol. Petrozavodsk Karelian Rese. Cen. RAS, pp. 96-112 (1994).

Kundu, I., P.K. Bandyopadhyay and D.R. Mandal: Prevalence of helminth parasites infecting Channa punctatus Bloch, 1793 from Nadia district of West Bengal. J. Agric. Vet. Sci., 8, 41-46 (2015).

Linton, E.: Fish parasites collected at Woods Holein 1898. United States Fish Commission Bulletin (for 1899), 19, 267-304 (1900).

Luque, J.L. and R. Poulin: Use of fish as intermediate hosts by helminth parasites: A comparative analysis. Acta. Parasitol., 49, 353-361 (2004).

Maurya, R., R. Gupta and A.M. Saxena: Taxonomic re-descriptions and a review of the status of Prosorhynchoides spp. (Digenea: Bucephalidae) infecting some freshwater fishes of India. Comp. Parasitol., 85, 159-176 (2018). 
Moller, H. and K. Anders: Diseases and parasites of marine fishes. Kiel Moller, p. 365(1986).

Motwani, M.P. and C.V. Srivastava: On the phyllodistomes from the urinary bladder of siluroid fishes. (Trematoda: Gorgoderiidae). Indian J. Helminthol.,13, 93-99 (1961).

Mukhesh, K. and R.K. Gambhir: Two new trematodes from a Loach, Schistura manipurensis from a hill stream of Manipur, India. Int. J. Eng. Comput. Sci., 6, 8190-8192 (2016).

Ningthoukhongjam, I., R.S. Ngasepam, B. Chabungbam and M. Shomorendra: Helminth parasites infection of the fishes of Nambol locality, Bishnupurdistrict, Manipur. Int. J. Curr. Res., 7, 11299-11302 (2015).

Odhner, T.: Mitteilungen zur Kenntnis der Distomen. Centr Bakt. Parasitol., 31, 58-69 (1902).

Olfers, J.F.M.: de DeVegetatvis et AnimatisCorporibus in Corporibus animates reperiun discommentarius. Pars.I. Berolini, p. 45 (1816).

Pandey, K.C. and S.K. Tewari: SEM studies on Bucephalopsis karvei Bhalerao, 1937, an intestinal parasite of the fish, Xenentodon cancila (Ham.). Proc. Anim. Sci., 93, 527-533 (1984).

Park, C.W., J.S. Kim, H.S. Joo and J. Kim: A human case of Clinostomum complanatum infection in Korea. Korean J. Parasitol., 47, 401-404 (2009).

Poulin, R. and S. Morand: Parasite biodiversity. Washington, D.C., Smithsonian Institution Books. p. 216 (2004).

Qian, M.B., J. Utzinger, J. Keiser and X.N. Zhou: Clonorchiasis. Lancet, $387,800-10$ (2016).

Rai, S.L.: Observation on the life history of Phyllodistomum srivastavai sp. nov. (Gorgoderidae). Parasitology, 54, 43-51 (1964).

Rim, H.J.: Clonorchiasis: An update. J. Helminthol., 79, 269-281 (2005).

Saichua, P., C. Nithikathkul and N. Kaewpitoon: Human intestinal capillariasis in Thailand. World J. Gastroenterol., 14, 506-510 (2008).

Sarwat, M.S.: A new species of genus Phyllodistomum (Braun, 1899), (Digenea: Gorgoderidae, Looss, 1901) from freshwater fish Mastacembelus armatus Aurangabad (M.S.) India. Recent Res. Sci. Technol., 3, 11-13 (2011).

Sen, J.M.: On a new species of Phyllodistomum Braun, 1899 (Digenea: Gorgoderidae), a parasite of freshwater fish, Channa punctatus (BI.) from Betwa River, Bundelkhand Region Jhansi, UP, India. Curr. World Environ., 9, 207 (2014).

Sen, J. and S.F. Siddiqui: A new gorgoderid trematode of genus Phyllodistomum (Digenea: Gorgoderidae), a parasite of fresh water fish, Xenentodon cancila (BI.) from Matatila reservoir, Jhansi, India. Flora and Fauna (Jhansi)., 19, 158-160 (2013).

Sharmin, S., H. Khanum and Md.H. Uddin: Endohelminth infection in
Xenentodon cancila (Hamilton-Buchanan,1822) (Belonidae) from Chandpur, Bangladesh. Univ. J. Zool. Rajshahi. Univ., 22, 117-1233 (2003).

Shomorendra, M., A.N. Jha and K. Pankaj: Seasonal occurrence of helminth parasites in fishes Loktak lake, Manipur. Uttar Pradesh J. Zool., 25, 23-27(2005).

Singha, R., M. Shomorendra and D. Kar: Parasite infection of three freshwater fishes in Dolu Lake, Silchar, Assam. Int. J. Fish Aquat. Stud., 2, 125-127 (2015).

Srivastava, C.B.: Platyhelminthes Vol 1. (Supplement). TrematodaDigenea. The Fauna of India and the adjacent countries. Zoological Survey of India, Calcutta, p.163 (1982).

Srivastava, H.D.: Anew gorgoderid trematode from the urinary bladder of an Indian migratory fish, Belone strongylura. Indian. J. Vet. Sci. Anim. Husb., 8, 91-393 (1938).

Srivastava, C.B. and B.S. Chauhan: A review of Indian Gasterostomes (Trematoda). Records Zoological Survey of India, 67, 1-13 (1973).

Thapa, S., D.B. Jyrwa and V. Tandon: Platyhelminth parasite spectrum in edible freshwater fishes of Meghalaya. In: Current Trends in Parasitology. Proceedings of the $20^{\text {th }}$ National Congress of Parasitology, Shillong, India. (Eds.: V. Tandon, A.K. Yadav, B. Roy). Panima Publishing Corporation, p.113-125 (2008).

Tandon, V., R. Chakravarty and B. Das: Four new species of the genus Lytocestus (Caryophyllidea, Lytocestidae) from edible cat fishes in Assam and Meghalaya, India. J.Parasit. Dis., 29, 131-142 (2005).

Tripathi, Y.R.: Studies on parasites of Indian fishes. 5 Acanthocephala. Rec. Indian Mus., 54, 61-99 (1959).

Vankara, A.P., M. Hemalatha, C.S. Kalyan and C. Vijayalakshmi: Metazoan parasite fauna of Clarias batrachus (Linn.) of River Godavari with description of a new species of digenean, Phyllodistomum batrachii sp. nov. Acta. Biol. Indica, 3, 593-604 (2014).

Yamaguti, S.: Studies on the helminth fauna of Japan. 1. Yamaguti, S.: Systema Helminthum. Acanthocephala of Vertebrates. Interscience Publishers Inc. New York, London, Vol. 5, p. 423 (1963b).

Yamaguti, S.: Systema helminthum. Vol 1. The digenetic trematodes of vertebrates. Interscience Publishers Inc. New York, London., p. 575 (1958).

Yamaguti, S.: Synopsis of the digenetic trematodes of Vertebrates. Vol. 1 \& 2, Keigaku Publishers, Tokyo., p.1074 (1971).

Yooyen, T., C. Wongsawad, K. Kumchoo and M. Chaiyapo: A new record of Clinostomum philippinensis (Valasquez, 1959) in Trichogaster microlepis (Gunther, 1861) from Bung Borapet, Nakhon Sawan, Thailand. South east Asian. J. Trop. Med. Pub. Hlth., 37, 99-103 (2006). 